\begin{abstract}
Iranica
Abstracta Iranica Revue bibliographique pour le domaine irano-aryen

Volume 34-35-36 | 2017

Comptes rendus des publications de 2011-2013
\end{abstract}

\title{
Sharon R. Steadman, Gregory McMahon (eds.). Ancient Anatolia. 10.000-323 B.C.E.
}

\section{Astrid Nunn}

\section{(2) OpenEdition}

1 Journals

\section{Édition électronique}

URL : http://journals.openedition.org/abstractairanica/41463

DOI : 10.4000/abstractairanica.41463

ISSN : 1961-960X

Éditeur :

CNRS (UMR 7528 Mondes iraniens et indiens), Éditions de l'IFRI

\section{Référence électronique}

Astrid Nunn, «Sharon R. Steadman, Gregory McMahon (eds.). Ancient Anatolia. 10.000-323 B.C.E. », Abstracta Iranica [En ligne], Volume 34-35-36 | 2017, document 16, mis en ligne le 15 juillet 2016, consulté le 29 septembre 2020. URL : http://journals.openedition.org/abstractairanica/41463 ; DOI : https://doi.org/10.4000/abstractairanica.41463

Ce document a été généré automatiquement le 29 septembre 2020.

Tous droits réservés 


\title{
Sharon R. Steadman, Gregory McMahon (eds.). Ancient Anatolia. 10.000-323 B.C.E.
}

\author{
Astrid Nunn
}

\section{RÉFÉRENCE}

Sharon R. Steadman, Gregory McMahon (eds.). Ancient Anatolia. 10.000-323 B.C.E. Oxford, 2011, 1174 p., env. 300 ill. en noir et blanc.

1 Quatre chapitres de cet opus magnum sont consacrés à l'archéologie de l'Age du Fer en Anatolie. Rien d'achéménide n'est mentionné pour l'Anatolie centrale (p. $415 \mathrm{sq}$.) et très peu pour l'Anatolie du sud-est (p. 443-463). Ce sont les Grecs qui marqueront de leur griffe l'Anatolie de l'ouest (Alan M. Greaves, p. 500-514). Le manque de matériel achéménide pourrait être expliqué par la politique libérale des rois achéménides et par le fait que les élites locales resteront au pouvoir. En Anatolie de l'est émerge à la fin du $\mathrm{V}^{\mathrm{e}} \mathrm{s}$. av. J.-C. la nouvelle céramique de la « Western Triangle Ware » (L. Khatchadourian, p. 464-499, sur l'Anatolie et l'Arménie). Ces chapitres sont complétés par quelques pages sur les populations nouvelles (K. Sams, p. 614-616) et par un chapitre sur la présence grecque (K. W. Harl, p. 752-774) d'après les sources écrites. Un chapitre entier est enfin consacré à la ville de Sardes (C. H. Greenewalt Jr., p. 1112-1130). Cette monographie offre une excellente introduction à l'histoire et à l'archéologie de l'Anatolie. Qui veut en savoir plus se référera aux bibliographies et à des ouvrages plus abondement illustrés. 


\section{AUTEURS}

\section{ASTRID NUNN}

Université de Munich 